\title{
Report of Stranding of Striped Dolphin Stenella coeruleoalba (Meyen, 1833) in Mersin Bay (Northeastern Mediterranean Sea, Turkey)
}

\author{
Deniz AYAS1, Hasan Deniz AKBORA1,2, Nuray ÇİFTÇi'1, Deniz ERGÜDEN33,*
}

${ }^{1}$ Faculty of Fisheries, Mersin University Yenişehir Campus, 33160, Mersin, Turkey

${ }^{2}$ Department of Biological Sciences, Faculty of Arts and Sciences, Eastern Mediterranean University, Famagusta 99628, North Cyprus via Mersin 10, Turkey ${ }^{3}$ Department of Marine Sciences, Faculty of Marine Sciences and Technology, Iskenderun Technical University, TR 31220 Iskenderun, Hatay, Turkey ORCID ID: Deniz AYAS: https:/ / orcid.org/0000-0001-6762-6284; Hasan Deniz AKBORA: https:/ / orcid.org/0000-0002-6647-866X; Nuray ÇIFTÇI: https://orcid.org/0000-0002-2925-0332; Deniz ERGÜDEN: http:/ / orcid.org/0000-0002-2597-2151

\begin{tabular}{llll}
\hline Received: 06.11.2019 Accepted: 08.12.2019 $\quad$ Published online: $20.12 .2019 \quad$ Issue published: 20.12 .2019 \\
\hline
\end{tabular}

\begin{abstract}
On 08 April 2019, a mature female striped dolphin Stenella coeruleoalba (Meyen, 1833), $185 \mathrm{~cm}$ in length (TL), was found dead across the shores of the Mersin Naval Museum, Mersin on the northeastern Mediterranean coast of Turkey. Striped dolphins may accidentally enter the fishing nets, which may be one of the reasons for their death. Although this species has been classified as Vulnerable in the IUCN list, considering the frequency of deaths among this species, the necessity to develop species conservation strategies for the Mediterranean was once again proven by the death of this individual.
\end{abstract}

Keywords: Dolphin, Delphinidae, Record, Turkish Mediterranean coast.

\section{Mersin Körfezi'ndeki (Kuzeydoğu Akdeniz, Türkiye) Çizgili Yunus Stenella coeruleoalba'nın (Meyen, 1833) Boğulma Raporu}

Öz: 08 Nisan 2019 tarihinde Türkiye'nin Doğu Akdeniz kıyısında Mersin Deniz Müzesi açıklarında 185 cm uzunluğa sahip bir adet çizgili yunus Stenella coeruleoalba (Meyen, 1833) ölü olarak bulunmuştur. Çizgili yunuslar, balıkçı ağlarına tesadüfen girebilirler bu durum da onların ölüm nedenleri arasında gösterilebilir. Tür IUCN listesinde hassas olarak sınıflandırılmış olsa da bu türün ölüm vakalarının sıklığı düşünüldüğünde, Akdeniz için türe ait koruma stratejileri geliştirilmesi gerekliliği, bu bireyin ölümü ile de bir kez daha ortaya konmuştur.

Anahtar kelimeler: Yunus, Delphinidae, Kayıt, Türkiye Akdeniz sahili.

Stenella coeruleoalba (Meyen, 1833) is a dolphin species belonging to order Cetacea and family Delphinidae (Rice, 1998). This species was first described as Delphinus coeruleoalbus in 1833 by the German zoologist Franz Julius Meyen from the southwest Atlantic (Kinzelbach, 1997; Van Waerebeek et al., 1998). The striped dolphin S. coeruleoalba is widely distributed in tropical, subtropical, and temperate waters (Van Waerebeek et al., 1998).

Striped dolphin is the common name of this species. They have a smooth body, with a thin waist, and a beak. The upper part of the body is dark-gray. There is a lightgray pattern specific to the species extending from the head area to the base of the dorsal fin. They have a thin dark band located between the upper jaw and the eyes extending towards the flippers to the bottom of the tail. The upper part of the beak is entirely darker in color and sometimes, the tip part is pale (Still, Harrop, Stenton, \& Dias, 2019).

Although they can be found in groups of 1 to 500 individuals, they often live in groups of 20-30 in tropical, subtropical, and warm seas. They mostly prefer deep waters beyond the continental shelf regions and rarely coastal areas (Still et al., 2019).

In the literature, the length of $S$. coeruleoalba is given as $100 \mathrm{~cm}$ at the time of birth. The first reproductive age in males is $6.7-8.7$ and the length is $210-219 \mathrm{~cm}$. The early reproductive age in females is 7.1-8.8, and the equivalent length is $209-216 \mathrm{~cm}$. They enter the breeding season 3 times a year with 4-5 month intervals (Miyazaki, 1977).
The first published record of the striped dolphin $S$. coeruleoalba in the Mediterranean coast of Turkey (Göksu Delta, Silifke) was documented by Kinzelbach (1997) and reported as an incidental capture of one individual in July 1996. Although Öztürk, Salman, Öztürk, \& Tonay (2007) states that the dolphin fishery in Turkish waters is banned, this species had been incidentally caught in the swordfish driftnet fisheries in the Aegean and Mediterranean parts of Turkey (Öztürk, 1996; Öztürk \& Öztürk, 1998; Öztürk, Öztürk, \& Dede, 2001).

In the Mediterranean, dolphins are under continuous pressure due to whaling, drowning in fishing net, and marine pollution. S. coeruleoalba are mainly fed with species which have commercial value and targeted by fishermen (Pulcini, Angradi, \& Sanna, 1993; Blanco, Anzar, \& Raga, 1995). Thus, while fishers and dolphins try to hunt the same species, they involuntarily reside in the same environment. For this reason, S. coeruleoalba is often caught as by-catch (Aguilar, 2000).

The striped dolphin has limited records, although it is common in the Mediterranean Sea coasts of Turkey. Up to date, three individuals of striped dolphins were recorded in the eastern Mediterranean, Turkey (Okuş et al., 2006; Dede, Saad, Fakhri, \& Öztürk, 2012).

Although the occurrence of the striped dolphin species in the Mediterranean was reported before, this species is infrequent in the northern part of the Mediterranean, Turkey. The present study reports the occurrence of a dead striped dolphin, which represents the 
second confirmed record in the Mersin Bay coast of Turkey.

On 08 April 2019, a mature female striped dolphin, Stenella coeruleoalba, $185 \mathrm{~cm}$ in total length (TL), was found dead across the shores of the Mersin Naval Museum $\left(36^{\circ} 46^{\prime} 45.6^{\prime \prime} \mathrm{N}\right.$; $34^{\circ} 36^{\prime} 06.4^{\prime \prime}$ E) in the northeastern Mediterranean coast of Turkey. The sampling point of the species in the northeastern Mediterranean Sea was presented in Figure 1. With the help of information provided in a study from Silifke, identification of the species was performed and necessary measurements taken (Kinzelbach, 1997). Its weight is $114 \mathrm{~kg}$ (The weight was measured with a hook scale (SF-912 $300 \mathrm{Kg}$ ) with a sensitivity of $100 \mathrm{~g}$ ). The specimen is buried to obtain the skeleton of the individual. After obtaining the skeleton of the sample, it will be deposited in the Museum of the Systematic, Faculty of Fisheries, Mersin University, (Catalogue no: MEUMC-19-11-002).

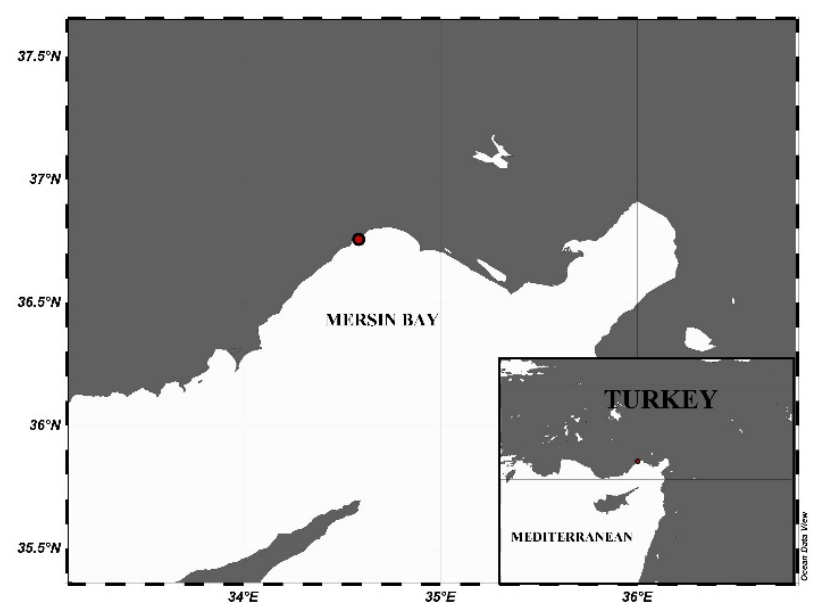

Figure 1. The red mark indicates the location where the sample found

Due to the wounds on the skin, it is thought that she was caught in a fishing net and drowned. According to the information given about the maturity stages of $S$. coeruleoalba in Miyazaki (1977), our sample was a mature female. The female specimen was measured as $185 \mathrm{~cm}$ total length, from the snout tip to the anterior base of the dorsal fin was $77 \mathrm{~cm}$, and length of the flipper was $20 \mathrm{~cm}$. Necessary measurements (body and skull) agree with the descriptions of Kinzelbach (1997). However, Kinzelbach (1997) reported as the total actual length of the female $S$. coeruleoalba was approximately $191 \mathrm{~cm}$, from the snout tip to the anterior base of the dorsal fin as $81 \mathrm{~cm}$; length of the (shrunken) flipper $23 \mathrm{~cm}$ for $S$. coeruleoalba from Goksu Delta (Silifke Turkey). The most critical parameters of the skull and body measurements of a female striped dolphin $S$. coeruleoalba specimen was obtained and the measurements compared with the other previous records in Mersin Bay (Kinzelbach, 1997). Values are shown in Table 1.

In this study, the skull measurements of our specimen and other previous record in the Mersin Bay are almost similar. These values are shown in Table 1. Our specimen is found somewhat smaller than the previous reported striped dolphins in the Silifke, Turkey (N.E. Mediterranean).

Every year a lot of dolphins are dying because of bycatch. Marsili, Casini, Marini, Regoli, \& Focardi, (1997) reported the stranding of cetaceans along the
Mediterranean coasts as a regular event. These dolphins are dying because of natural causes such as old age or as a result of accidents such as strike by boats, ingestion of foreign objects (including plastic bags), or drowning in fishing nets.

Table 1. The crucial measurements of S. coeruleoalba compared with the previous Mediterranean record

\begin{tabular}{lcc}
\hline Measurements $\mathbf{( c m )}$ & \multicolumn{2}{c}{ Values } \\
\hline Specimen No & 1 & 1 \\
\hline References & $\begin{array}{c}\text { Present Study } \\
\text { N.E. Mediterranean } \\
\text { (Mersin, Turkey) }\end{array}$ & $\begin{array}{c}\text { Kinzelbach (1997) } \\
\text { N. Mediterranean } \\
\text { Silifke, Turkey }\end{array}$ \\
\hline Total length & 185 & 191 \\
The snout tip to the & 77 & 81 \\
$\begin{array}{l}\text { anterior base of the } \\
\text { dorsal fin }\end{array}$ & 20 & $23^{*}$ \\
Length of the flipper & 35.2 & $>35.8$ \\
Condylobasal length & 19.1 & $>19.4$ \\
Rostrum length & 10.1 & 10.4 \\
Breadth of rostrum & 18.4 & 19.0 \\
near base & 20.6 & 21.2 \\
Preorbital breadth & 31.5 & $>32.3$ \\
Postorbital breadth & 6.4 & 6.6 \\
Mandible length & & \\
Mandible height & &
\end{tabular}

*This value was reported as shrunken

Mediterranean population of $S$. coeruleoalba is categorized as Vulnerable on the IUCN Red List (IUCN, 2019) and Least Concern global Red List of Threatened Species category (Braulik, 2019). The number of mature individuals for this species is unknown (Aguillar \& Gaspari, 2012). Besides, this species listed in Appendix II of the Convention on International Trade in Endangered Species (CITES) (IUCN, 2019). However, there is still a need for conservation strategy for $S$. coeruleoalba and other dolphins in the Mediterranean Sea.

The striped dolphins may be taken incidentally in fishing nets. As a result, human interactions can be a cause or contributing factor in the deaths of striped dolphins in the Mediterranean Sea. Thus, conservation measures should be enforced at the local and national level more intensively for this species.

In this study, we aimed to report a S. coeruleoalba who drowned as a result of by-catch in Mersin Bay (Northeastern Mediterranean Sea, Turkey).

For preventing non-target fishing, it is recommended to design perceptible nets in water considering the biological characteristics of by-catch species.

Acknowledgments: This study was supported by the Research Fund of Mersin University in Turkey with Project Number: 20172-AP2-2353.

\section{References}

Aguilar, A. (2000). Population biology, conservation threats and status of Mediterranean striped dolphins (Stenella coeruleoalba). Journal of Cetacean Research and Management, 2, 17-26.

Aguilar, A., \& Gaspari, S. (2012). Stenella coeruleoalba. The IUCN Red List of Threatened Species 2012: e.T20731A2773889. Retrieved from https://www.iucnredlist.org/species/16674437/16674052

Blanco, C., Anzar, J., \& Raga, J.A. (1995). Cephalopods in the diet of the striped dolphin Stenella coeruleoalba from the western Mediterranean during an epizootic in 1990. Journal of Zoology, 237, 151-158. https://doi.org/10.1111/j.1469-7998.1995.tb02753.x

Braulik, G. (2019). Stenella coeruleoalba. The IUCN Red List of Threatened Species 2019: e.T20731A50374282. Retrieved from https://www.iucnredlist.org/species/20731/50374282 
Dede, A., Saad, A., Fakhri, M., \& Öztürk, B. (2012). Cetacean sightings in the eastern Mediterranean Sea during the cruise in summer 2008. Journal of Black Sea/Mediterranean Environment, 18(1), 49-57.

IUCN. (2019). The IUCN Red List of Threatened Species. Version 2019-2. Retrieved from http://www.iucnredlist.org.

Kinzelbach, R. (1997). A record of striped dolphin Stenella coeruleoalba (Meyen, 1833) from the Turkish Mediterranean Sea coast. Zoology in the Middle East, 15, 15-18. https:// doi.org/10.1080/09397140.1997.10637733

Marsili, L., Casini, C., Marini, L., Regoli, A., \& Focardi, S. (1997). Age, growth and organochlorines (HCB, DDTs and PCBs) in Mediterranean striped dolphins Stenella coeruleoalba stranded in 1988-1994 on the coasts of Italy. Marine Ecology Progress Series, 151, 273-282. https://doi.org/10.3354/meps151273

Miyazaki, N. (1977). Growth and reproduction of Stenella coeruleoalba off the Pacific Coast of Japan. Science Report Whales Research Institute, 2, 1-48.

Okuş, E., Yüksek, A., Yokeş, M.B., Yılmaz, I.N., Aslan-Yılmaz, A., Karhan, S.Ü., Demirel, N., ... \& Gazioglu, C. (2006). Determination of biodiversity of coastal and marine areas of Gökova special environmental protection area (Report No. 2006-1). Ankara, Turkey, Ministry of Environment and Forestry of Turkey Press., 504 pp.

Öztürk, B. (1996). Yunuslar ve Balinalar (Whales and Dolphins). Istanbul, Türkiye, Anahtar Yayınları, 119 pp.

Öztürk, B., \& Öztürk, A.A. (1998). Cetacean strandings in the Aegean and Mediterranean coasts of Turkey. Rapport de la Commission International de la Mer Méditerranée, 35, 476-477.

Öztürk, B., Öztürk, A.A., \& Dede, A. (2001). Dolphin bycatch in the driftnet fishery in the Aegean Sea. Rapport de la Commission International de la Mer Méditerranée, 36, 308.

Öztürk, B., Salman, A., Öztürk, A.A., \& Tonay, A. (2007). Cephalopod remains in the diet of striped dolphins (Stenella coeruleoalba) and Risso's dolphins (Grampus griseus) in the eastern Mediterranean Sea. Vie et Milieu, 57(1/2), 53-59.

Pulcini, M., Angradi, A.M., \& Sanna, A. (1993). Stomach contents of striped dolphins (Stenella coeruleoalba) from the south-central Tyrrhenian coast. European Research on Cetaceans, 6, 37-39.

Rice, D.W. (1998). Marine mammals of the world: systematics and distribution. The Society for Marine Mammalogy Special Publication, 4, 1231

Still, R., Harrop, H., Stenton, T., \& Dias, L. (2019). Europe's Sea Mammals Including the Azores, Madeira, the Canary Islands and Cape Verde. New Jersey, USA, Princeton University Press, 208 pp.

Van Waerebeek, K., Felix, F., Haase, B., Palacios, D.M., Mora-Pinto, D.M., \& Munoz Hincapie, M. (1998). Inshore records of the striped dolphin, Stenella coeruleoalba, from the Pacific coast of South America. Report of the Meeting of the International Whaling Commission, 48, 525-532. 